\title{
Changing Perceptions Of Conflict: The Beneficiaries Of Intra-Ethnic Conflict Among The Abakuria Community, Kenya
}

\author{
Kerubo R. Omari
}

\begin{abstract}
Conflict in many parts of the world has become part of people's life resulting in massive deaths, displacement of people and trail of destruction to property leading to manmade disasters. In Kenya, conflict is experienced as warring groups engage in armed and non-armed conflicts. A peculiar case is that of the Abakuria ethnic group, where inter-clan conflicts have become perpetual. The mechanisms used in managing the conflict have been both inadequate and ineffective as the conflicts keep recurring. It is on this backdrop that this study aimed at evaluating beneficiaries to the conflict with a view of establishing the root causes of intra-ethnic conflict. The study employed descriptive survey, ethnography and explanatory research designs. The target population for the study was 52,338 comprising of members of the indigenous conflict management systems, members of provincial administration, local and international Non-governmental Organizations, Community Based Organizations, Faith Based Organizations, community policing members, members of peace committees, civic leaders, District security team, warriors and community members/victims to the conflict. From the target population, a sample 638 was selected using purposive sampling, stratified sampling, transect walk and snowball sampling techniques. Data were collected using questionnaires, in-depth interviews and focus group discussion. Quantitative data generated from the study were analysed descriptively while qualitative data were analysed following the five steps of thematic data analysis: transcription, open coding, axial coding, selecting codes and formation of themes. The study established that there were several categories of beneficiaries to intra-ethnic conflict including government officials, traders, consumers, households, politicians and members of the traditional institutions. The study recommends that there is need to enlighten the community on the negative effects of intra-ethnic conflict. In addition, cartel of beneficiaries of such conflict who work to catalyse the conflict for their own benefit should be severely punished.
\end{abstract}

KEY WORDS: Intra-Ethnic Conflict, Conflict, Beneficiaries to conflict, Kuria conflict

\section{INTRODUCTION}

Ethnic conflict in every society is almost inevitable, as most of the conflicts are resource based yet resources are often scarce and competition for them leads to unequal distribution. In fact, conflict is a phenomenon that has caused global devastation. However, the developing world, and especially Africa, has been the hardest hit. According to Wanyama (2000), conflicts have cost Africa a fortune as they are so intense that they lead to massive destruction of property, loss of lives and population displacements among many other evils. In support of this, Leith and Solomon (2000) opine that ethnic conflicts are among the major challenges facing the world, as they have a compounding influence on political, economic and social stability. In Kenya, conflicts between different clans or groups of a community have occurred since time immemorial. However, such cases have been rampant in the recent past. According to Sikuku (2011), there has been protracted violence in Mt. Elgon region between the Sabaot Land Defence Forces of Soy clan and Moorland Forces of the Mosop clan leading to massive loss of lives and property.

In dealing with these conflicts, the conventional efforts have proved futile as the conflicts keep recurring in most communities. The case of Somali where there has been conflict for over two decades, the Niger delta where there is a never ending conflict explains this case better as not even UN and AMISOM peace keepers have managed to calm the situation, a revelation that there must be under current forces with not only ignite but also catalyse the conflict.

In Kenya, several communities have also been in never ending conflicts. To begin with, the conflict between the Turkana and the Pokot communities, the Pokot and the Marakwet, the Pokot and the Tugens, the Tugens and the Samburu dates to hundreds of years and not even government interventions have managed to calm down the situation (Ruto, et al 2004). The communities traditional mechanisms for managing conflict for instance the Adakar (Livestock Neighborhood Association) which is an important traditional governance and conflict resolution institution which resolves conflicts at community/clan level and the Ekitoe Ng'ekeliok which deals with issues that are beyond the capacity of Adakars especially conflicts between the various clans and those between the Turkana and other communities has not borne any fruits. The same case applies among other Kenyan communities, the Abakuria being one of them.

\section{Statement of the Problem}

Conflict between the different Abakuria clans has been going on since time immemorial (Abuso, 1980). For instance, according to Marwa (2001), between 1986 and 1996, there were a number of inter-clan conflicts among various Abakuria clans that resulted in massive human and non-human destruction. In another case, OCHA (2009) noted that between July and September 2009, conflict in Kuria District between the Nyabasi and Bwiregi clans displaced over 20,000 persons and left a trail of deaths and destruction of property.

In managing conflicts between Abakuria clans several mechanisms have been put in place such as government intervention through disarmament, establishment of police stations, peace caravans by the National cohesion and integration commission, peace efforts by the religious groups and even the indigenous approaches. However, even with these institutions in place, conflict between various clans in the community has persisted for a long period of time. It is from this backdrop that this paper sought analyse the beneficiaries to intra ethnic conflict between the Abakuria clans.

2505 | P a g e

January 2018

https://cirworld.com 


\section{Justification of the study}

The study was justified since Kenya as a country and Africa in general has experienced conflicts, many of which have persisted for a very long time and therefore the findings of the study will help in establishing and understanding the forces behind the conflict with a view of addressing the problem.

In addition, the inter-clan armed conflict among the Abakuria has persisted despite the existence of conflict management institutions such as the local county security administration and the Abakuria indigenous conflict management mechanism known as Inchama. The findings of this study will help in suggesting more effective ways of managing this conflict.

Finally, the study gives an input to the body of knowledge with its contribution to the understanding of intra-ethnic conflict and the beneficiaries to the conflict.

\section{Study Area}

The Abakuria are an ethnic and linguistic group resident in the Tarime and Serengeti districts of the Mara region in Northern Tanzania, and the larger Kuria District (divided into Kuria west and Kuria east districts) of Nyanza Province, Migori County in southwest Kenya. However, the data for the research was collected from the Abakuria resident in Kenya, who spread over the larger Kuria Districts: Kuria West consisting of the Bagumbe and Bukira clans and Kuria East composed of the Nyambasi and Bwirege clans. According to the 2009 census, the Kuria East District had 81,883 persons and 13,513 households spread in two divisions Kegonga and Ntimaru, While Kuria west District had 174,293 persons and 28,257 Households (KNBS, 2010), spread in two administrative divisions Mabera and Kehancha, therefore a total of population of 256,176 persons and 51,770 households. The study area is shown in figure 3.1 .



Figure 3.1: Map of the Study Area 


\section{Source: District Development Plan Kuria District 2008-2013 RESEARCH METHODOLOGY}

The study employed descriptive survey research design to collect quantitative and numbered data using questionnaires. Ethnographic research design was also used. Since indigenous systems of managing affairs among the Abakuria clans have been in place since time immemorial (Abuso, 1980), this design was found appropriate. The study also employed explanatory sequential design. In the words of Creswell and Plano (2011), the design is a procedure for collecting, analyzing and mixing both qualitative and quantitative methods in a single study to understand a research problem.

The target population for the study was 52,338 as shown in table 1 . This comprised of members of the Abakuria indigenous conflict management institutions that is the Inchama and institutions under it which include Avaragoli, Iritongo, Sungusungu and Ihama, who are the custodians of information on indigenous conflict management. Also included were members of provincial administration, the District security team, Civic leaders, Non Governmental Organisations, Community Based Organisations, Faith Based Organisations, Peace committees, community policing committees, warriors and the community.

To obtain the required information for this study, the members of the target population were stratified and a sample drawn from each. This was embraced to ensure each category of the target population was captured and to get a sample representative of the population. After stratification, the executive (the chairman, secretary and treasurer) members of the Inchama, Iritongo, Sungusungu and ihama formed the sample and hence purposively selected. Since there were four clans each with a distinct structure, a total 48 members from 176 were selected for inclusion in the study. The choice of the executive members was informed by the fact that they are the custodians of information for their respective groups thus information obtained from them representative of other members.

Key informants from members of the Interior ministry also formed the sample. This included 2 Deputy County Commissioners and 5 Assistant County Commissioners who were selected using the census method. Also forming part this cluster were 12 chiefs and 23 assistant chiefs who were purposively selected from conflict hotspots. In total the cluster had a sample of 42 participants.

Table 1: Sample Size

\begin{tabular}{|c|c|c|}
\hline Population Description & Target Population & Sample \\
\hline Members of indigenous institutions & 176 & 48 \\
\hline Provincial Administration & 77 & 42 \\
\hline Civic Leaders & 13 & 7 \\
\hline DAPC, OCS and OCPD & 13 & 13 \\
\hline $\begin{array}{ll}\text { Non-governmental, } & \text { Community } \\
\text { Based organizations and Faith } \\
\text { Based Organizations }\end{array}$ & 110 & 33 \\
\hline $\begin{array}{l}\text { Community policing and peace } \\
\text { committee }\end{array}$ & 145 & 37 \\
\hline Warriors & 40 & 8 \\
\hline Community members (Victims) & 51770 & 450 \\
\hline Total & 52,338 & 638 \\
\hline
\end{tabular}




\section{Source: Researcher Data 2013}

The Civic leaders (Members of County Assembly) also formed the sample. Out of the total 15 Civic leaders, 7 were purposively selected from conflict hotspot areas for inclusion in the study. The Sub County security team also formed the sample. Because their work covered the conflict hotspot and non-hotspot areas, all the 13 members were included in the sample thereby census sampling

The executive committee members (Chairman, secretary and treasurer) of three NGOs, four CBOs and four FBOs also formed part of the sample. Therefore, from the total of 110 members, 33 were purposively selected for the study. Also included were community policing members and members of the local peace committees. From a target of 145 members, the executive members (chairman, secretary and treasurer) of Sub-County and Divisional community policing and peace committees (36) and the peace monitor (1) were purposively selected thus a total sample of 37 participants. This was based on the assumption that the executive committee members were the custodians of information for their respective groups. This category of respondents helped in providing information related to the role of indigenous institutions in managing conflict, the challenges that could be affecting them in the management of conflict and the complimentary role that they play in managing conflict.

Also forming part of the study were 40 Abamuraa (warriors) involved in conflict out of whom only 8 formed the sample and were selected through snow balling and convenience sampling. Those selected were the warrior leaders and their deputies. Also included in the study were households selected by transec. From the households selected, the household head at the time of conducting the study was included in the study upto a desired sample of 450 . The sample of 450 was distributed across the conflict hotspots in the two districts each representing a quadrant with 225 respondents. In total, a total sample size of 638 was selected. This was determined according to Mugenda and Mugenda (2003) formula $\mathrm{n}=\mathrm{Z}^{2}$ (p.q)/d $\mathrm{d}^{2}$ which states that for populations larger than 10,000 , a sample of 384 or more is adequate and representative of the entire population. The researcher chose a sample of 638 which was more than 384 in order to reduce chances of some questionnaires not being returned thus falling short of the set target.

The data were collected using questionnaires, interviews and focus group discussions. Quantitative data were analysed descriptively using frequencies and percentages and presented in tables and charts while qualitative data were analysed using the five thematic steps: transcription, open coding, axial coding, selecting codes and formation of themes. (Jwan and Ong'ondo, 2011)

Table 1: Sample Size

\begin{tabular}{|l|l|l|}
\hline Population Description & Target Population & Sample \\
\hline Members of indigenous institutions & 176 & 48 \\
\hline Provincial Administration & 77 & 42 \\
\hline Civic Leaders & 13 & 7 \\
\hline DAPC, OCS and OCPD & 13 & 13 \\
\hline $\begin{array}{l}\text { Non-governmental, Community Based } \\
\text { organizations and Faith Based Organizations }\end{array}$ & 110 & 33 \\
\hline Community policing and peace committee & 145 & 37 \\
\hline Warriors & 40 & 8 \\
\hline Community members (Victims) & 51770 & 450 \\
\hline \multicolumn{1}{|c|}{ Total } & $\mathbf{5 2 , 3 3 8}$ & $\mathbf{6 3 8}$ \\
\hline
\end{tabular}

\section{Source: Researcher Data 2013}

\section{Results and Discussion}

Persistence and recurrence of conflict among the different Abakuria clans is an indicator that there could be silent forces that benefit from it and would not like it ended. Kemp (2004) opines that when analyzing conflict, one must start from the assumption that there are people who have a vested interest in the instability. Such people thrive in an environment in which they can exploit resources, exercise coercion, and accumulate enough wealth and control to keep them in power. In extreme forms, internal conflicts are the deliberate creation and maintenance of 'war economies', situations which accrue significant benefits for an array of local and international actors (Keen, 1998). Data for this section emanated from openended questions, interviews and Focused Group Discussions. The results are presented in figure 4.6. 




Figure 4.6: Beneficiaries to the Conflict

\section{Source: Research Data 2013}

The findings revealed the following categories of beneficiaries of conflict:

\section{a). Government officials:}

245 (59.9\%) of the community members indicated that government officials including District Commisioners (DC), District Officers (DO) and Chiefs benefitted from cattle rustling. Some members of these institutions in collaboration with Iritongo and Inchama levied inflated fines on offenders, in order to draw higher payments for their arbitrating services.

At another level, perpetrators of livestock theft, bribed chiefs, being the security officers at the lowest level, in order for them to protect and conceal their criminal activities. An interview revealed that in 2005 the serving District commissioner of the larger Kuria District then had accumulated a herd of up to 100 cattle, which he sold to the Kenya Meat Commission. In another incident, it was reported that the Kuria East District Commissioner(DC) between 2008 and 2010 used to benefit from livestock stolen by the Bwirege clan members from other clans and in exchange defended the clan whenever there were complaints about their open animosity. He was eventually transferred to another station upon mounting pressure from the public.

In support of this, a warrior noted;

What we do is well known to the chiefs, DO's and even DC's. There is no way we can have conflict for several years without knowing who is causing it. We cannot have cattle raids day in day out without knowing the perpetrators. We eat together...(An interview with a warrior from Bagumbe clan, $25^{\text {th }}$ October, 2012).

\section{b).The police department:}

The policewas also a great beneficiary of the conflict. The study established that the warriors, in their raids, not only used homemade guns but also bought or hired others from the police. The police then would share the proceeds from the raids. In addition, most perpetrators in the conflict who were handed over to the police were never charged since they bribed their way out either in person or through politicians whose interests they seemed to serve. A respondent in an interview noted;

Can you ask yourself how many rounds of ammunition we use when we have armed conflict for several months/?....... lot. Ask yourself where we get them from... it is them (referring to the police) who sell the ammunition to us. We either pay in cash or give cows in return (Interview with warrior, Nyabasi clan, $8^{\text {th }}$ December, 2012).

\section{c). Politicians:}

$196(47.9 \%)$ of the community members indicated that politicians, too, were beneficiaries of conflict. Some politicians financed the conflict in order to reap from the loot acquired by perpetrators. One case noted was that of a councillor in Ntimaru who had many guns for hire. Those hiring paid a certain fixed fee, or in exchange for four (4) cattle per gun, or per raid. He was also known to buy stolen livestock at very low prices for resale either to the Kenya Meat Commission or the neighbouring Tanzania. Other politicians from the area also used armed conflict to fight, oppress or intimidate their opponents especially during electioneering periods. They used the warriors to destabilise their competitors' regions. In support of this a warrior quipped; 
The politicians in Kuria have to pledge loyalty to us because without us they are finished. We protect them and even campaign for them and in return if we need money from them, we get it with ease...they must accept our demands otherwise if they refuse they will have it rough... remember what happened to our MP in 2007 (referring to an incident where the area MP was almost killed)...that was a lesson to others (Interview with a Warrior Nyabasi clan, $8^{\text {th }}$ December, 2012).

\section{d). Traders/businessmen/middlemen:}

It was indicated by $154(40.0 \%)$ of the community members that some people involved in business also benefited from the Kuria conflict. This category of beneficiaries was considered to operate at two levels. At the first level were traders who purchased stolen livestock at low prices and sold them at higher prices in urban centres or to the Kenya Meat Commission where they could realise relatively high profits. This category also included livestock butchery owners who bought the stolen livestock and slaughtered them by night for sale in butcheries. In the process, they were said to be making huge profits as they normally bought the livestock at low prices. Some warriors owned butcheries too where they slaughtered cattle acquired through theft. Also in this category were transport service providers who charged extra high fees to transport the stolen livestock from raiding points to the market.

At the second level, the dealers in arms and weapons used in raiding and conflict were also key beneficiaries to conflict. These included persons who made and sold bows, arrows, spears, guns and other traditional weapons used during raids and inter-clan war; and the sellers of guns and ammunition. In most cases, before raids and planned conflicts, members of the community replenished their stock of weapons in a bid to make their raids successful. In addition, after raids the community members refurbished worn out weapons thus enhancing marketability for such weapons.

\section{e). Indigenous Institutions:}

Members of indigenous institutions in the management of conflict including the Inchama, Avaragoli, Iritongo, Sungusungu and Ihama also befitted from the conflict. This was supported by $158(38.6 \%)$ of the community members. To begin with, the Inchama, Avaragoli and Iritongo received a share of stolen livestock for successful raids as a token for providing charms to protect the warriors who were responsible for conducting raids. In addition, when they charged fines to offenders, they exaggerated the fees which was always paid in form of livestock. The Sungusungu and Ihama as well benefitted from the conflict as they were paid after successfully returning stolen livestock and punishing suspected offenders in a bid to force them to admitting to the crimes they were accused of committing. An interview with a warrior also revealed the same as he noted;

For every successful raid that we conduct the Inchama and Avaragoli must be paid something (referring to livestock), you don't give them, then you will have nowhere to run to next time you want to go for a raid... who will provide you with charms?...(Interview with warrior Nyabasi clan, $8^{\text {th }}$ December, 2012).

\section{f). Consumers:}

Other beneficiaries were consumers as agreed by $134(32.8 \%)$ of the community members. In this category were families who received stolen livestock either directly as domestic assets, those that received them in form of dowry and consumers of meat and milk in cultural ceremonies. This was supported by FGD participants as one reiterated;

Can you imagine the magnitude of celebration in that home where dowry of a herd of 10 cows is paid as dowry? Such a family is a great beneficiary of conflict and will always pray that it continues so that they continue enjoying the trickle down effects. Now young men no longer fear to marry as cows are readily available at affordable prices. (Interview with peace monitor, $8^{\text {th }}$ December, 2012).

\section{CONCLUSIONS AND RECOMMENDATIONS}

These findings point to the fact that conflict benefited an array of people both within and outside the community. The beneficiaries could ignite, fuel and sustain the conflict for their own personal gains. In view of this it is recommended that the government and other stakeholders undertake a comprehensive awareness creation on the impacts of the conflict. The mass media can play a key role in this. The awareness programme should be a whole package highlighting the negative impacts of the conflict vis a vis benefits of maintaining peace not only in the study area but in the entire country. This can be achieved by comparing the same districts in conflict and peace situations, the development scenario in conflict zones and peaceful areas of the same district and development situations in conflict prone areas and peaceful districts. Such benchmarking will make people in conflict zones compare and contrast development levels in their areas with those of other areas thus making informed choices of whether to continue with conflict or abandoning it for their own common good.

In addition, government officials, politicians and other leaders found culpable of perpetuating conflict should be met with the full force of the law. 


\section{REFERENCES}

1. Abuso, M. (1980). A Traditional History of the Abakuria CAD 1400-1914. Nairobi: Kenya

a. Literature Bereau

2. Awulachew, S.B., Gupta, A.D., Babel, M.S., \& Edossa, C.D. (2007). Indigenous Systems of Conflict Resolution in Oromia, Ethiopia.

3. Caracelli, V. J \& Green, J.C. (1997). Advances in Mixed Method Evaluation: the Benefits and Challenges of Integrating diverse Paradigm. New Directions for Evaluation No 74, San Fransisco: Jossey-Bass.

4. Choundree, R.G.B. (1999). Traditional Conflict Resolution in South Africa. African Journal of Conflict Resolution, 1(1), 40-65.

5. Creswell, J.W (2013). Educational Research Planning: Conducting and Evaluating Quantitative and Qualitative Research ( $4^{\text {th }}$ ed.). Thousands Oak, CA: Sage.

6. Creswell, J.W \& Plano-Clark, V.L (2011). Designing and Conducting Mixed Method Research (2 ${ }^{\text {nd }}$ ed.). Thousands Oak, CA, Sage.

7. Hussein, M. K. (2011). Intra-state Conflict and Indigenous- based Conflict Resolution Mechanisms in Malawi: the Role of Public Affairs Committee. Africa Security Review, 20 (1), 26-39.

8. Marwa, O. (2001). Partnership for Peace: Conflict Monitoring Report from Kuria. Retrieved from http://www.partnershipforpeace.eu on $22^{\text {nd }}$ May 2012.

9. Mensah, N (2008). African Conflict "Medicine": An Emerging Paradigm Shift in African Conflict Resolution? In Lyons,T. and Khadiagala,G.M. (Eds.), Conflict Management and African Politics: Ripeness, Bargaining and Mediation, pp.135-144. New York: Routledge, Taylor and Francis

10. Okoh, R.N. \& Egbon, P.C. (1999). Fiscal Federalism and Revenue Allocation: The Poverty of the Niger Delta, in The Nigerian Economic Society, 1999, Fiscal Federalism and Nigeria's Economic Development. Selected Papers Presented at the 1999 Annual Conference, Abuja, Nigeria, 405-420 (Chapter 19).

11. OCHA (2009). Kuria Inter-Clan Clashes Situation Report. Retrieved from http://ochaonline.un.org/kenya on $15^{\text {th }}$ April 2013.

12. Ruto, P, Mohamed, A. and Masinde, I (2004). Indigenous Democracy: Traditional Conflict Resolution Mechanisms. Intermediate Technology Development Group East Africa, 17(1):11-90.

13. Sikuku, A.K. (2011). The Land Question and Inta-Ethnic Conflict in Squatter Enclaves of Mt.Elgon Region, western Kenya. Un-published Thesis, Masinde Muliro Universty-CDMHA.

14. Solomon, H. \& Leith, R. (2000). On Ethnicity and Ethnic Conflict Management in Nigeria. African Journal of Conflict Resolution, 2(1), 21-33.

15. Wanyama, F.O. (2000). Conflict Resolution in Africa by Africans: A Review of Past Experiences and Prospects for the Twenty-first Century. In P.G. Okoth (Ed.), Africa at the Biginning of the $21^{\text {st }}$ Century. Nairobi: Nairobi University Press. 